A.V. VARABEI ${ }^{1}$, Y.N. ARLOUSKI ${ }^{1}$, N.A. LAGODICH ${ }^{2}$, V.F. AREHAY ${ }^{3}$

\title{
X-RAY ENDOBILIARY AND ENDOSCOPIC INTERVENTIONS IN COMPLEX TREATMENT OF INTRAHEPATIC CHOLANGIOLITHIASIS IN HEPATICOJEJUNOSTOMY STRICTURES
}

\author{
SBE "Belarusian Medical Academy of Postgraduate Education” 1, \\ ME “Minsk Regional Clinical Hospital 2, \\ SE "Republican Scientific and Practical Center of Oncology and Medical \\ Radiology named after N.N. Alexandrov" ${ }^{3}$, Minsk \\ The Republic of Belarus
}

Цель. Улучшить результаты лечения пациентов с внутрипеченочным холангиолитиазом при стриктурах гепатикоеюноанастомозов (ГЕА) с использованием малоинвазивных методов

Материал и методы. За период с 2009 по 2016 гг. в нашем центре находилось 25 пациентов со стриктурами гепатикоеюноанастомозов, из них 6 пациентов имели внутрипеченочный холангиолитиаз. Окончательный диагноз рубцовой стриктуры гепатикоеюноанастомоза и холангиолитиаза выше соустья устанавливали по данным МРТ-холангиографии, двухбаллонной энтероскопии и чрескожной чреспеченочной холангиографии. 13 (52\%) пациентам выполнена регепатикоеюностомия, 12 (48\%) - малоинвазивные вмешательства: лазерная вапоризация соустья с использованием двухбаллонной энтероскопии (7 пациентов) и литоэкстракция при двухбаллонной энтероскопии (1), транспеченочная холангиоскопия (2) с лазерной литотрипсией (1), баллонная дилятация стриктур гепатикоеюноанастомозов (4), литоэкстракция (4), совместно с двухбаллонной энтероскопией (методика «рандеву») (1), стентирование (2). Комбинированная малоинвазивная технология сводилась к выполнению одновременных вариантов чрескожных чреспеченочных эндобилиарных вмешательств (баллонная дилятация, лазерная вапоризация конкрементов через холангиоскоп, стентирование долевых протоков и зоны гепатикоеюноанастомоза) и эндоскопических с использованием двухбаллонного энтероскопа (литоэкстракция, санация).

Результаты. Летальности после малоинвазивных вмешательств не было. Среди ранних осложнений имелись обострение холангита (5 пациентов); инкрустация желчными конкрементами стентов у 1 пациента (в течение 1 года после процедуры), потребовавшая повторной открытой операции; рецидивы стриктур ГЕА (2 наблюдения), для ликвидации которых в сроки от 6 мес. до 2 лет выполняли регепатикоеюностомию. В отдаленном периоде у $5(10,9 \%)$ оперированных пациентов в сроки от 6 мес. до 3 лет наблюдался рецидив стриктуры ГЕА. Всем этим пациентам выполнили регепатикоеюностомию.

Заключение. Комбинированные эндоскопические и эндобилиарные миниинвазивные методы лечения холангиолитиаза при стриктурах гепатикоеюноанастомоза показывают хорошие непосредственные и отдаленные результаты.

Ключевые слова: желчные протоки, стриктура, гепатикоеюноанастомоз, холангиолитиаз, антеградные вмешательства, двухбаллонная энтероскопия, литотрипсия

Objectives. To improve the treatment results of patients with the intrahepatic cholangiolithiasis in hepaticojejunostomy strictures using minimally invasive methods.

Methods. During the period from 2009 till 201625 patients with hepaticojejunostomy strictures were being treated in our center. 6 of these patients had coexistent intrahepatic cholangiolithiasis. The final diagnosis of hepaticojejunostomy stricture and cholangiolithiasis above the anastomosis was established according to MRIcholangiography, double balloon enteroscopy and percutaneous transhepatic cholangiography. Rehepaticojejunostomy was performed in $13(52 \%)$ patients. $12(48 \%)$ patients were subject to minimally invasive intervention such as laser vaporization of anastomosis using double balloon enteroscopy (7 patients) and lithoextraction with double balloon enteroscopy (1), transhepatic cholangioscopy (2 patients) with laser lithotripsy (1), balloon dilatation of the stricture of rehepaticojejunoanastomosis (4), lithoextraction (4), including with double balloon enteroscopy («randezvous» procedure) (1), stenting (2). Combined minimally invasive procedures was reduced to performing simultaneous variants of percutaneous transhepatic endobiliary interventions (balloon dilatation, laser vaporization of bile duct concrements through the cholangioscope, stenting of the lobar ducts and the hepaticojejunoanastomoses zone) and endoscopic interventions using a double balloon enteroscope (lithoextraction, sanation).

Results. There were no lethal outcomes after minimally invasive interventions. Among early complications were the following: cholangitis aggravation (5 patients); incrustation of stents with bile concrements - in 1 patient (within 1 year after the procedure), requiring a reoperation; recurrences of HJA strictures (2), for the elimination of which in the period from 6 months till 2 years rehepaticojejunostomy was performed. In the long-term period, in 
$5(10.9 \%)$ of the operated patients in the period from 6 months up to 3 years the recurrence of HJA stricture was observed. All these patients were subject to rehepaticojejunostomy.

Conclusions. Combined endoscopic and endobiliary techniques of treatment and endobiliary minimally invasive correction of rehepaticojejunostomy strictures and cholangiolithiasis demonstrate good immediate and long-term results.

Keywords: bile ducts, stricture, hepaticojejunostomy, cholangiolithiasis, antegrade interventions, double balloon enteroscopy, lithotripsy

Novosti Khirurgii. 2017 Sep-Oct; Vol 25 (5): 467-475

$\mathrm{X}$-ray Endobiliary and Endoscopic Interventions in Complex Treatment

of Intrahepatic Cholangiolithiasis in Hepaticojejunostomy Strictures

A.V.Varabei, Y.N. Arlouski, N.A. Lagodich, V.F. Arehay

\section{Introduction}

Benign strictures of the hepaticojejunoanastomosis (HJA) occur in $8-40 \%$ of the observations after reconstructive operations on the bile ducts and are one of the urgent challenges of the biliary surgery $[1,2]$. According to the data of many authors, from 62.3 to $75 \%$ of such patients are subject to repeated surgical interventions because of the development of recurrences of the anastomotic strictures [3, 4]. With each subsequent operation, the frequency of strictures increases with the subsequent occurrence of recurrent cholangitis, cirrhosis and portal hypertension [5]. Intrahepatic cholangiolithiasis is usually a secondary manifestation of the HJA strictures.

Currently, the main way to correct the strictures of HJA is to conduct a repeat reconstructive operation - rehepaticojejunostomy. Nevertheless, the performance of such interventions is accompanied by a significant number of postoperative complications, reaching $42.9 \%$, with the postoperative lethality at the level of 1.7-5.6\%. [6, 7].

Correction of intrahepatic cholangiolithiasis against the background of HJA strictures by means of traditional reconstructive operations is aggravated by numerous complications and at present stage is a cause for the development of sparing minimally invasive methods for the recovery of the bile outflow.

Objectives. To improve the treatment results of patients with the intrahepatic cholangiolithiasis in hepaticojejunostomy stricture using minimally invasive methods.

\section{Methods}

For the period from 2009 to 2016, 25 patients with HJA strictures were being treated at the Republican Center for Reconstructive Surgical Gastroenterology and Coloproctology after previous reconstructive operations on the bile ducts, also with the development of intrahepatic cholangiolithiasis (24\% of patients). The development of the latter against the background of HJA strictures occurred within the period from 1 to 3 years.

In the clinic until 2009, the repeated reconstructive surgery had been mainly conducted in case of HJA strictures recurrence. In connection with the emergence of modern equipment (double-balloon enteroscope (DBE) - since 2009, x-ray surgical equipment - since 2010 , oral choledochoscope since 2016), we have stated to use the complex minimally invasive treatment of HJA strictures, also in combination with cholangiolytiasis.

Minimally invasive operations were performed in $12(48 \%)$ patients after previous reconstructive operations on the biliary ducts (Table), the rest 13 $(52 \%)$ - repeated reconstructive operations in the form of rehepaticojejunostomy.

All these patients had a clinic of cholangitis and jaundice on admission. The examination included general clinical and ultrasound studies, computed tomography and magnetic resonance cholangiography (MRI-CG).

The treatment-diagnostic algorithm developed and used in our clinic in case of HJA strictures is shown in Fig. 1.

Variants of minimally invasive interventions in HJA strictures complicated by cholangiolithiasis

\begin{tabular}{|c|c|c|c|}
\hline $\begin{array}{l}\text { Pathology before } \\
\text { operation }\end{array}$ & $\begin{array}{l}\text { Type of primary } \\
\text { operation }\end{array}$ & Variant of minimally invasive treatment & $\overline{\mathrm{n}}$ \\
\hline $\begin{array}{l}\text { Tumor of the head } \\
\text { of the pancreas }\end{array}$ & $\begin{array}{l}\text { Pancreaticoduodenal } \\
\text { resection }\end{array}$ & $\begin{array}{l}\text { Percutaneous transhepatic cholangioscopy }+ \text { laser lithotripsy } \\
+ \text { balloon dilation of HJA with lithoextraction }\end{array}$ & 1 \\
\hline $\begin{array}{l}\text { Cholangiocarcinoma } \\
\text { of the distal part of } \\
\text { choledochus }\end{array}$ & $\begin{array}{l}\text { Pancreaticoduodenal } \\
\text { resection }\end{array}$ & $\begin{array}{l}\text { Randezvous procedure: percutaneous transhepatic balloon } \\
\text { dilation of HJA + double balloon enteroscopy (DBE) with } \\
\text { lithoextraction }\end{array}$ & 1 \\
\hline \multirow{3}{*}{$\begin{array}{l}\text { Posttraumatic scar } \\
\text { stricture of the } \\
\text { hepaticocholedochus }\end{array}$} & Roux & DBE laser vaporization & 7 \\
\hline & hepaticojejunostomy & $\begin{array}{l}\text { percutaneous transhepatic balloon dilation with } \\
\text { lithoextraction+ stenting of HJA zone }\end{array}$ & 2 \\
\hline & & DBE lithoextraction & 1 \\
\hline
\end{tabular}




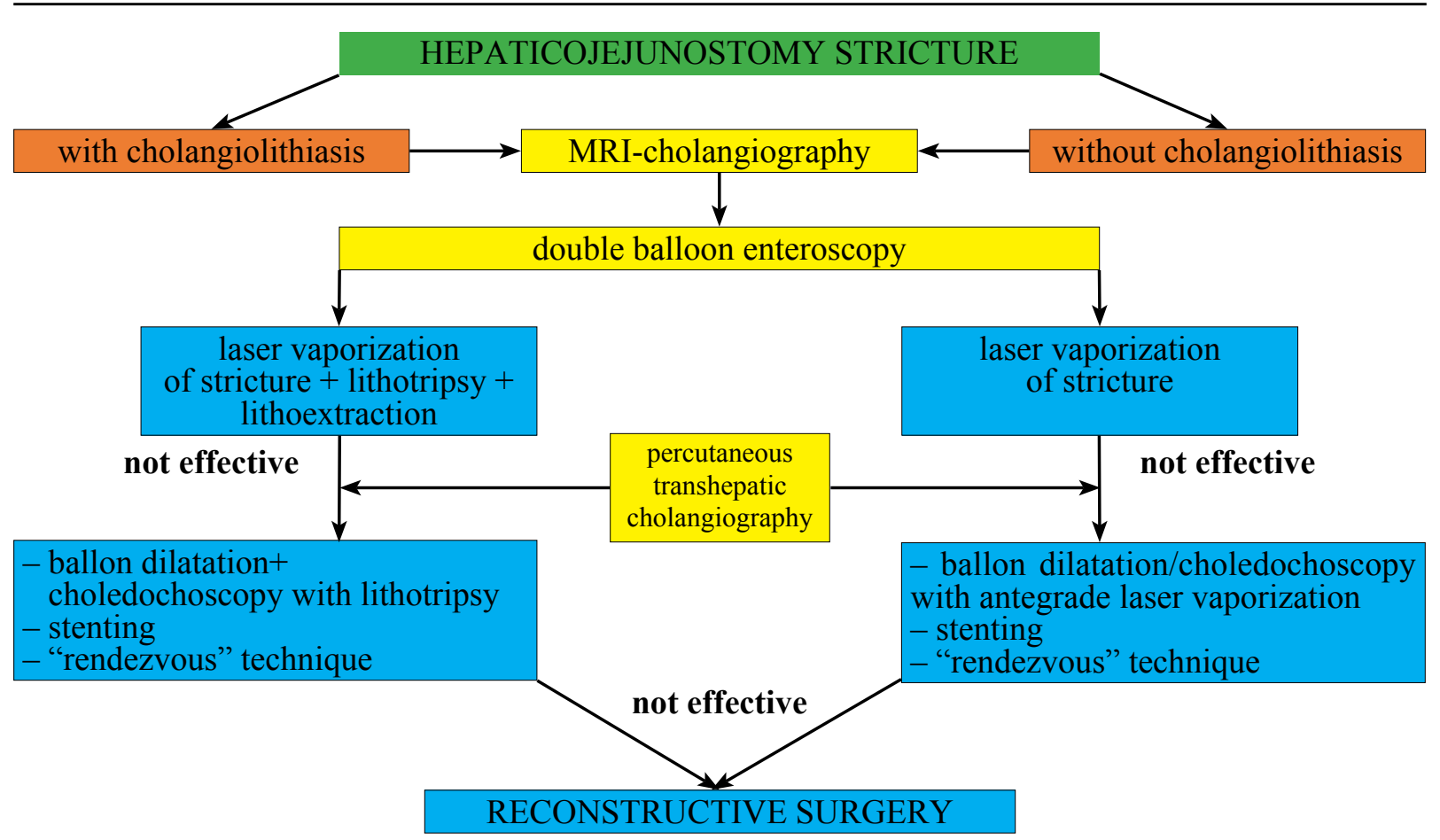

Fig. 1. Diagnostic and treatment algorithm in HJA strictures.

In patients with the diagnosed HJA stricture by MRT-CG or at the time of DBE, when the zone of anastomosis was reached, the laser recanalization of the anastomosis with the laser radiation of wavelength $1320 \mathrm{~nm}$ and the power of $12 \mathrm{~W}$ with a front light guide of $400 \mathrm{~m}$ was performed. The procedure was considered successful when an adequate amount of bile entered the Roux loop. Then the sanitation of the biliary tree was performed.

Combined minimally invasive technology was as follows. The first stage under the X-ray control, one performed the percutaneous puncture and catheterization of the bile ducts of the right or left lobe of the liver. In the lumen of the bile ducts, the intruder $10 \mathrm{~F}$ was injected, through which the cholangioscope of the SpyGlass system was guided through the conductor to their lumen. If there were conditions, a laser light guide $400 \mathrm{~m}$ was passed through its working channel and lithotripsy of concrements (wavelength $1440 \mathrm{~nm}$, power $12 \mathrm{~W}$ ) was carried out. In 4 patients, a balloon catheter with the diameter of 6-8 $\mathrm{mm}$ was passed through the introducer and a gradual dilatation of HJA stricture was done, followed by the further moving concrements to the jejunum loop by Roux. If the concrements were large, a mechanical lithotripsy with the balloon dilatator assisted by two-balloon enteroscopy "from below" ("rendezvous" technique) and their lithoextraction with forceps and the Dormia basket (1 observation) conducted through the working channel of the DB-enteroscope was performed.

In 2 patients, when there was a doubt about the adequacy of the balloon dilatation of HJA zone, the stenting with nitinol self-expanding stents of both lobar ducts through the HJA zone was carried out.

In all the observations, after finishing the procedure, the hepaticocholedochus biliary drainage Pig-Tail 6F conducted transhepatically was left in the loop lumen of the jejunum by Roux for 3-4 days to ensure the internal bile excretion and subsequent control of the effectiveness of minimally invasive treatment of HJA stricture.

\section{Results}

The final diagnosis of the HJA stricture and cholangiolithiasis above the anastomosis was established according to MRT-cholangiography, DBE and percutaneous transhepatic cholangiography. Therapeutic and diagnostic tactic was aimed not only to verify the stricture and intrahepatic concrements, but also to eliminate the causes of calculus formation by the use of minimally invasive antegrade and retrograde interventions for the restoration of choleretic function.

Despite the variety of methods for minimally invasive treatment of HJA strictures, the most convenient and effective, according to the literature, are percutaneous antegrade measures. This is due to the frequent inability to perform a "retrograde" procedure due to surgical altered anatomy of the small intestine after reconstructive surgeries, even in the presence of a two-balloon enteroscope and the corresponding experience of endoscopists.

There was no postoperative and post-manipulation lethality in the study. Among the early com- 
plications and consequences of minimally invasive interventions were the following: aggravation of cholangitis (5 patients); incrustation of stents with bile concrements in 1 patient (within 1 year after the procedure), requiring an open reoperation; recurrences of HJA strictures ( 2 observations), for the elimination of which in the period from 6 months up to 2 years rehepaticojejunostomy was performed.

In the long-term period, 5 (38.5\%) operated patients in terms from 6 months up to 3 years had the recurrence of HJA strictures. All these patients were subject to rehepaticojejunostomy.

In all these patients, methods of minimally invasive treatment in different variants included (table): DBE-laser vaporization (7 patients), DBElithoextraction (1), transhepatic cholangiography (2 patients) with laser lithotripsy (1), balloon dilatation of HJA stricture (4), lithoextraction (4), including with the support of two-gallon enteroscopy ("rendezvous" technique 1), stenting with nitinol self-expanding stents (2).

In 7 patients with severe mechanical jaundice (bilirubin from $100 \mathrm{mmol} / \mathrm{L}$ and more), DBE laser vaporization of HJA stricture was useful for reducing biliary hypertension before surgical treatment. In two cases, this procedure was final.

The following clinical observations with using combined minimally invasive methods are worth mentioning.

\section{Clinical observation 1.}

The female patient, 54 years old. She was admitted to the Republican Center for Reconstructive Surgical Gastroenterology and Coloproctology on 24.11.2016 with complaints of pain in the right upper quadrant, jaundice, fever. From the anamnesis it is known: in 2004 she received the combined treatment because of the rectum cancer and, and in 2012 - she was operated on because of the uterus cancer. 11.07.2013, due to the pancreatic cancer with spreading to the lower-horizontal branch of the duodenum (T4N1M0 st. IIIb), anterior gastroenterostomy was performed on the jejunum loop with the interintestinal anastomosis according to Brown, and on August 26, 2013 - radical gastro-pancreatoduodenal resection. Since May 2016, a clinic of cholangitis has developed: periodic abdominal pain, body temperature up to $38^{\circ} \mathrm{C}$, icterus of the skin. In this regard, she was treated. Before admission to our hospital, MRI cholangiography (15.11.2016) was performed: the intrahepatic ducts were enlarged. In the area of confluence, a filling defect of $5 \mathrm{~mm}$ was visualized. The total hepatic duct is $13 \mathrm{~mm}$, in its lumen there is an oval-shaped filling defect of $18 \times 8$ $\mathrm{mm}$. Choledochus is not distally visualized. In our center to verify cholangiolytiasis and to evaluate the possibility of minimally invasive intervention in HJA zone and to perform lithoextraction, an attempt was made of the double-balloon enteroscopy by Roux loop (05.12.2016). However, because of the adhesive process and atypical variant of the operation (two loops by Roux), the procedure was unsuccessful. Therefore, on December 7, 2016, percutaneous transhepatic cholangioscopy with laser lithotripsy, antegrade recanalization and balloon dilatation of HJA with lithoextraction and progression of concrements below the anastomosis in the jejunum loop by Roux were performed (Fig. 2).

The procedure was as follows. The posterior sectoral intrahepatic bile duct with cholangiography was punctured on the right in the VII

Fig. 2. Scheme of pathology and variant of minimally invasive intervention: Aa - pathology of HJA: 1 - concrements in the HC lumen, 2 - stricture of HJA, B - endobiliary intervention: 1 - cholangioscope with laser light guide, 2 - expanded HJA with crushed with laser concretions, 3 - balloon dilator.
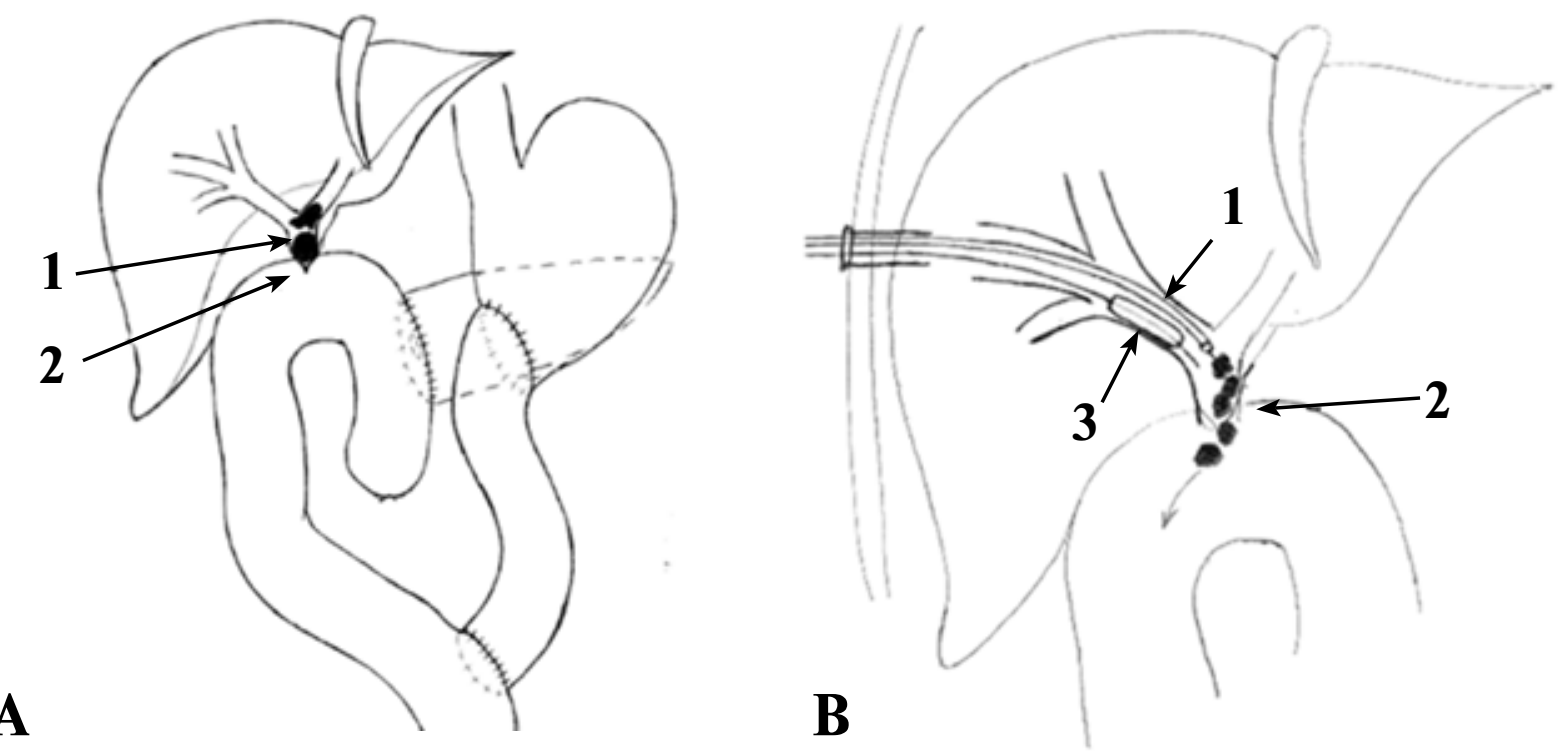
intercostal space along the midclavicular line: filling defects in the bile ducts $(15 \times 10 \mathrm{~mm})$ and hepaticholocholedochus $(20 \times 15 \mathrm{~mm})$ were determined. Contrast flow to the small intestine was weak. Recanalization of HJA by a conductor and catheter was performed. The catheter was removed. The introducer $10 \mathrm{~F}$ was put into the lumen of the bile ducts, through which acholangioscope was passed through the lumen of the bile ducts (see Fig. 2): tight calculus was visualized in the zone of confluence and HJA, closing the lumen of the duct and the zone of anastomosis. Laser lithotripsy of the concrement was performed (wavelength 1440 $\mathrm{nm}$, power $12 \mathrm{~W}$ ). After the lithotripsy, a balloon catheter of $10.0 \times 40.0 \mathrm{~mm}$ was inserted into the HJA zone and a balloon dilatation of HJA was performed with further movement of the calculi below the anastomosis and complete sanation of the biliary truct (Fig. 3). Through the introducer in the lumen of the jejunum, a control biliary drainage Pig-Tail $6 \mathrm{~F}$ was introduced. Internal bile outflow was regulated. 12.12.2016 - control percutaneous ranshepatic cholangiography (PTCHG) was carried out- the contrast freely arrives through a sufficiently extended anastomosis.

\section{Clinical observation 2.}

The female patient, 70 years old. She was admitted to the Republican Center for Reconstructive Surgical Gastroenterology and Coloproctology on 12.12.2016 with the complaints of pain in the right hypochondrium, jaundice, fever. From the anamnesis it is known: in 2014 - the pancreatoduodenal resection was performed in the oncological clinic for cholangiocellular cancer of the distal choledochus section. Since February 2016, a clinic of cholangitis has developed: periodic abdominal pain, fever up to $38{ }^{\circ} \mathrm{C}$, icterus of the skin. There was a periodic treatment of this state. Before admission to our clinic, MRI-HC (06.10.2016) was performed: the intrahepatic ducts were enlarged, the total hepatic duct was $21 \mathrm{~mm}$, in its lumen there was the defect of filling of the oval form $21 \times 9 \mathrm{~mm}$. Distally choledochus was not visualized.

In our Clinic, on 22.12.2016, in order to verify the diagnosis of cholangiolithiasis and the possibility of minimally invasive intervention in HJA zone and also of lithoextraction, a combined minimally invasive treatment was performed with simultaneous use of a double-balloon enteroscopy of the loop by Roux under the control of percutaneous transhepatic cholangiography. The procedure was as follows.

The posterior sectoral intrahepatic bile duct with cholangiography was punctured on the right in the VII intercostal space along the medium axillary line: the defect of filling in the lobar hepatic ducts, confluence and hepatitis choledochus $(20 \times 15 \mathrm{~mm})$ was determined. The contrast to the small intestine flew filiformly through stenosed HJA (Fig. 4). The right hepatic duct was catheterized; HJA was recanalized with a conductor and a catheter. A balloon catheter $10 \times 40 \mathrm{~mm}$ was inserted into the region of HJA stricture; dilatation was performed at a pressure of 12 atmospheres, 2 times for 1 minute. A twoballoon enteroscope is retrogressively applied to the anastomosis zone (Fig. 5). HJA stricture is enlarged after balloon dilatation, the lumen is blocked with calculus and puttylike bile - they were removed by the Dormia basket, conducted through the working channel of the DB-enteroscope (Fig. 6).

Fig. 3. Balloon dilatation of HJA: A - type of procedure (1 - zone of HJA, 2 - balloon dilator);

B - PTCHG after dilatation: an enlarged zone of HJA (indicated by the arrow) is visible and a free entry of contrast into the jejunum loop by Roux (1).
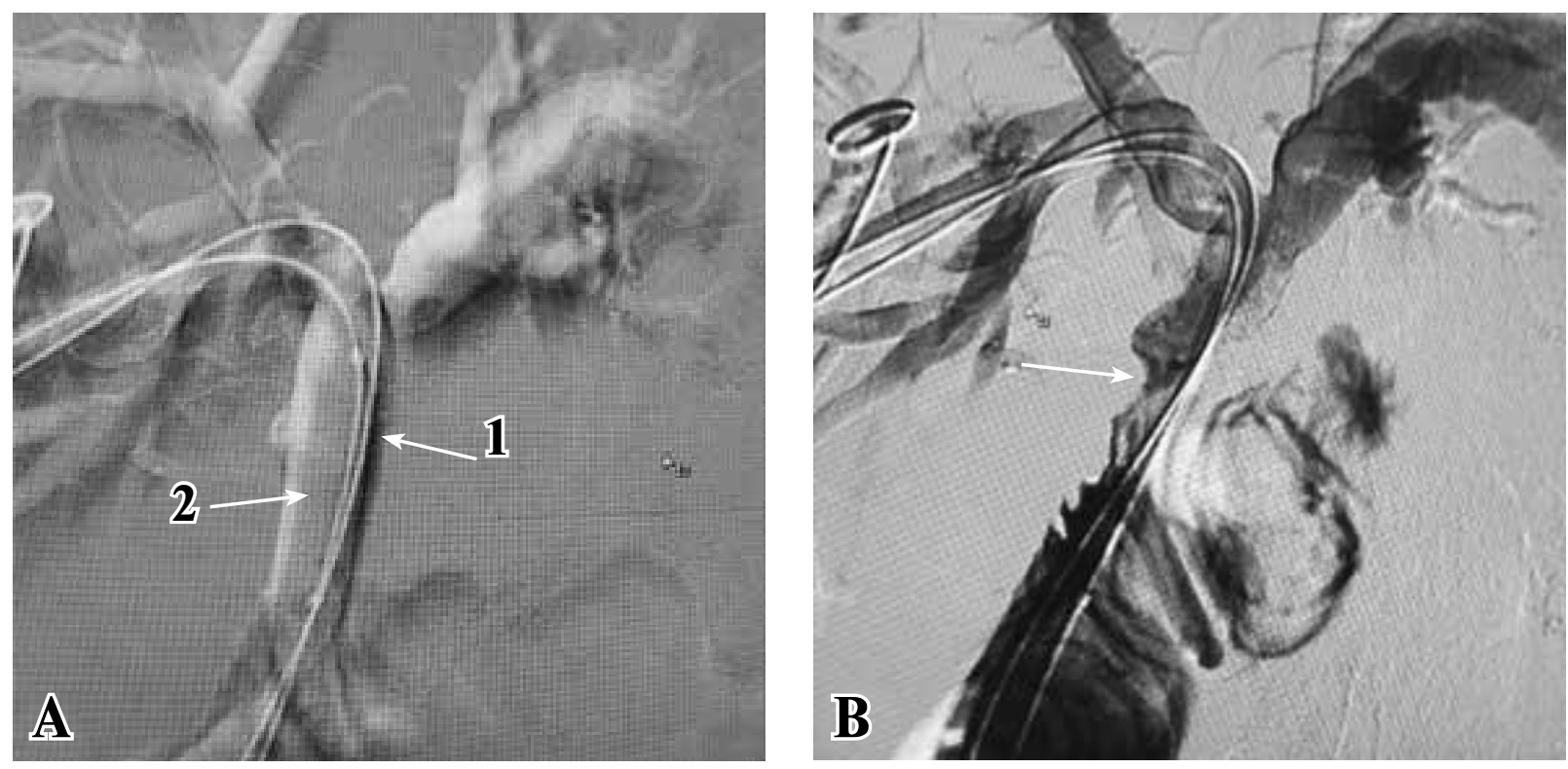

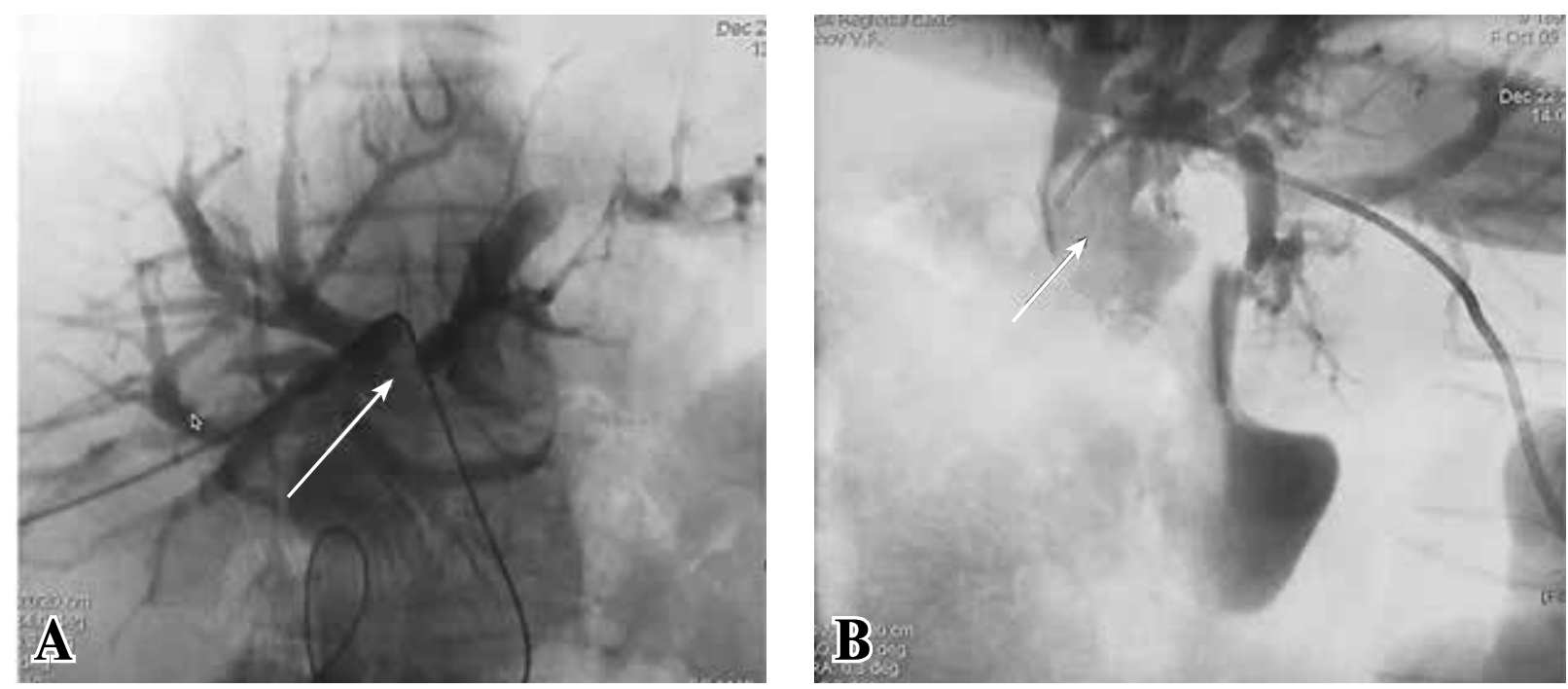

Fig. 4. PTCHG: A, B: a large-size concrement is visualized in the confluence area (indicated by arrows).
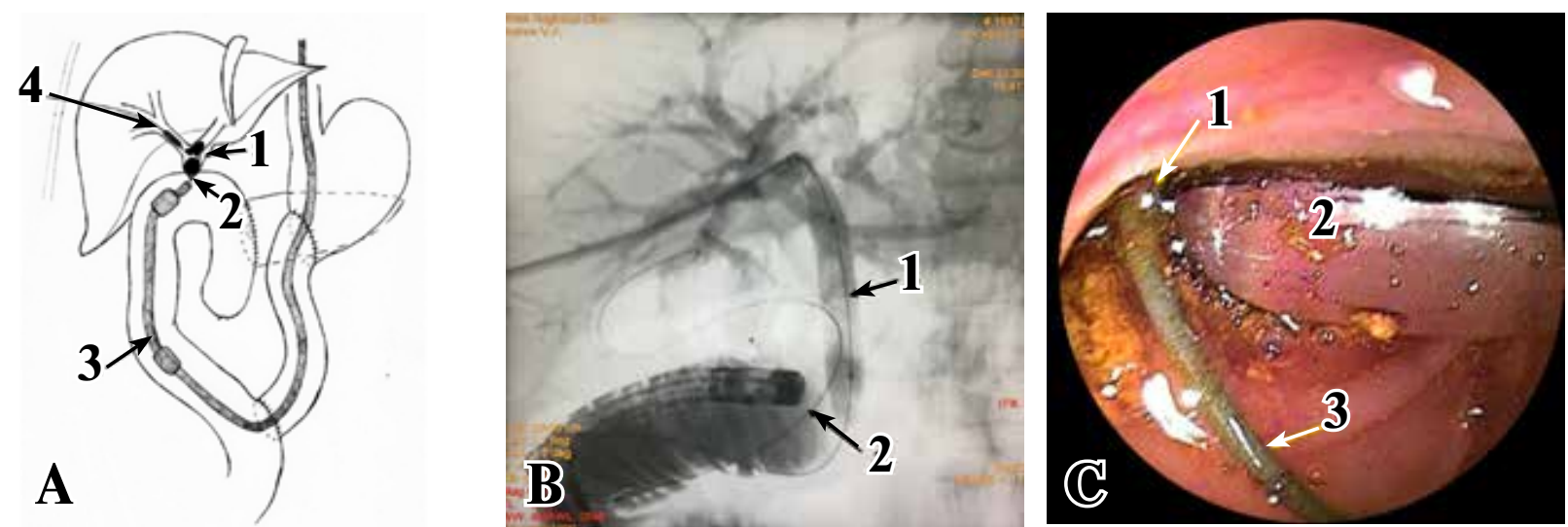

Fig. 5. A - scheme of pathology and procedure $(1-$ concrement in the $\mathrm{HC}$ above the anastomosis, $2-$ stricture HJA, 3 - two-balloon enteroscope, retrogressively moved to the loop by Roux to the zone of HJA, 4 - balloon dilator, conducted descendingly through the right lobar duct); B - PTCHG with balloon dilatation of HJA (1 - inflated balloon in the zone of HJA, 2 - two-balloon enteroscope); C - endoscopic photo (1 - zone of HJA, 2 - inflated balloon, 3 - catheter-conductor).
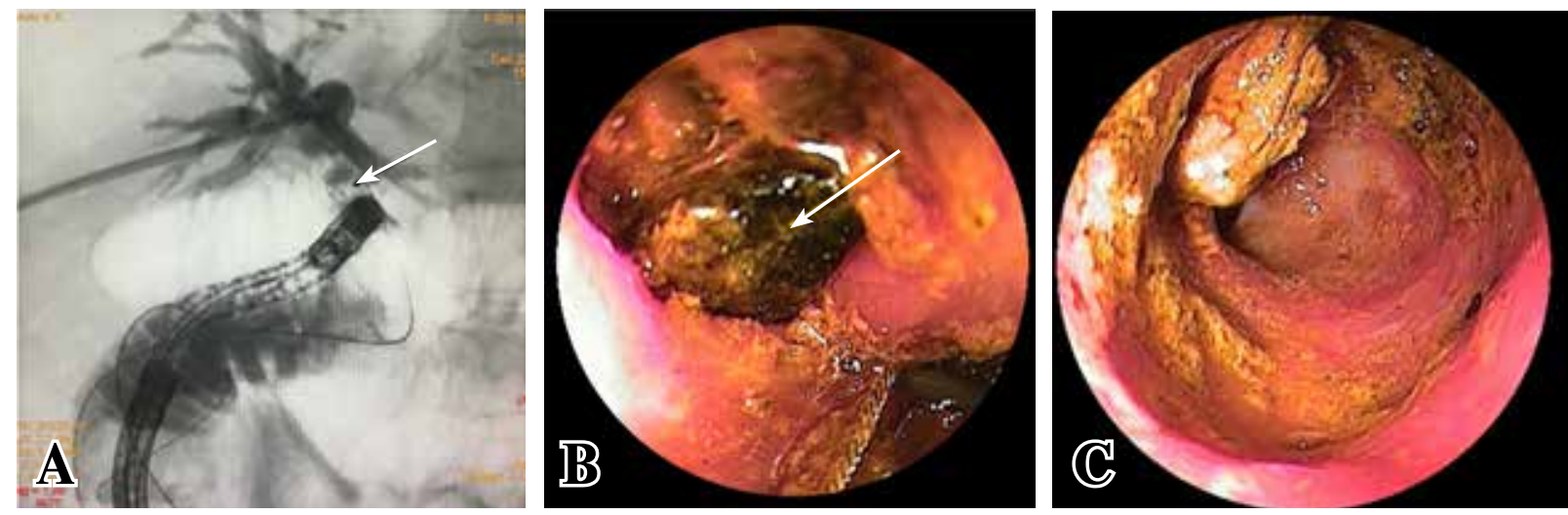

Fig. 6. A - PTCHG (the arrow indicates the concrement in the HC); B - the endoscopic photo (the arrow indicates the large calculus in HJA lumen); $\mathrm{C}$ - the endoscopic photo: the free lumen of HJA zone after lithoextraction.

These clinical observations demonstrate the possibility of the combination of minimally invasive $\mathrm{x}$-ray-endobiliary and endoscopic interventions in the above-described rare pathology: a combination of antegrade laser lithotripsy, lithoextraction and balloon dilatation of the narrowed-HJA zone with percutaneous transhepatic cholangiography and DB-enteroscopic assistance and minimally invasive retrograde surgical interventions through the working channel of the DB-enteroscope. 


\section{Discussion}

Benign strictures of biliodigestive anastomoses in combination with cholangiolithiasis are a rare pathology that occurs at a frequency of 10 to $30 \%$ at different times of the distant postoperative period [4]. Most of these patients (up to 75\%) are operated on repeatedly $[1,3]$.

This pathology can often be complicated by recurrent cholangitis, cholangiolithiasis, liver failure and biliary cirrhosis $[5,6]$. Thus, S.S. Negi et al. in the study revealed that after 3.8-14.8 months, fibrosis and cirrhosis develop as a result of violation of the bile outflow [7].

Traditional repeated reconstructive surgeries in HJA strictures and cholangiolithiasis refer to complex and traumatic interventions with a high risk of developing repeated strictures and a decrease in the life quality of patients [8]. According to numerous literature sources, it is noted that in $60-90 \%$ of cases with each subsequent operation, the stricture level becomes more complicated and approaches the IV-V type according to $\mathrm{H}$. Bismuth $[9,10]$.

In some cases, when performing repeated reconstructions, many authors use transhepatic framework drainage. However, it has many disadvantages: the formation of precipitates with drainage obturation; development of hemobiology, bile leaking, acute cholangitis; development of the syndrome of the undrained segment or the proportion of the liver, hepatic insufficiency, cholangiogenic liver abscesses [1, 11, 12].

Recently, minimally invasive methods have become increasingly common for the diagnosis and treatment of cholangiolithiasis against the background of HJA strictures: prolonged percutaneous transhepatic biliary drainage, percutaneous transhepatic cholangioscopy with balloon dilatation of the anastomosis, lithotripsy with lithoextraction with double-balloon enteroscopy (DBE), stenting $[13,14]$. The efficacy of percutaneous transhepatic interventions for HJA stricture, according to P.R. Mueller et al., ranges from 67 to $73 \%$ [15]. However, all these methods are more often used as a mono variant and are not always effective in such a performance. There are also technical difficulties for performing DBE in the case of surgically altered anatomy of the small intestine.

In our study, 10 of 12 patients $(83.3 \%)$ had a positive effect after minimally invasive interventions. In 2 observations, in connection with the developed HJA strictures, traditional reconstructive operations - rehepaticojejunostomy were performed.

In 2 cases after balloon dilatation of the HJA zone, no re-dilatation was required. According to many authors, such one-stage procedure has a positive effect in $73-85 \%$ of cases $[3,16]$.
In all patients, by the time the procedure had been completed, an adequate restoration of the bile outflow of bile in a loop by Roux was achieved, which was manifested by normalization of the relevant clinical and laboratory parameters. The results of the control surveys also indicate a good HJA patency.

The "rendezvous" technology developed by us (percutaneous transhepatic lithotripsy and "proximal" (antegrade) balloon dilatation of HJA stricture with the assistance a double-balloon enteroscope led distally (retrogressively) to the stricture in case of surgically altered jejunum anatomy) has a world priority.

\section{Conclusions}

1. In HJA strictures complicated by cholangiolithiasis, it is necessary to use minimally invasive $\mathrm{x}$-ray-endobiliary and endoscopic methods of correction, and if one of these methods is ineffective, their combination should be used.

2. The methods of correction of HJA strictures in combination with cholangiolithiasis, which has developed after reconstructive operations on the bile ducts, are a priority tool in elderly patients with comorbid pathology.

3. Combination of antegrade balloon recanalization or laser vaporization of HJA stricture with DB-endoscopic assistance and extraction of fragments of concrements followed by internal drainage or stenting are new, effective and safe treatment methods for cholangiolithiasis in the HJA scar strictures.

\section{Consents were obtained from the patients for all clinical cases reports presented in the article.}

\section{ЛИТЕРАТУРА}

1. Гальперин ЭИ, Чевокин АЮ. Факторы, определяющие выбор операции при «свежих» повреждениях магистральных желчных протоков. Анналы Хирург Гепатологии. 2009;14(1):49-56.

2. Schmidt SC, Langrehr JM, Hintze RE, Neuhaus P. Long-term results and risk factors influencing outcome of major bile duct injuries following cholecystectomy. Br J Surg. 2005 Jan;92(1):76-82. doi: 10.1002/bjs.4775.

3. Bonnel DH, Fingerhut AL. Percutaneous transhepatic balloon dilatation of benign bilioenteric strictures: long-term results in 110 patients. Am J Surg. 2012 Jun;203(6):675-83. doi: 10.1016/j.amjsurg.2012.02.001.

4. Gastaca M. Biliary complications after orthotopic liver transplantation: a review of incidence and risk factors. Transplant Proc. 2012 Jul-Aug;44(6):1545-49. doi: 10.1016/j.transproceed.2012.05.008.

5. Jung JY, Lee SK, Oh HC, Lee TY, Kwon SH, Lee $\mathrm{SS}$, et al. The role of percutaneous transhepatic cholangioscopy in patients with hilar strictures. Gut Liver. 2007 Jun;1(1):56-62. doi: 10.5009/gnl.2007.1.1.56.

6. Yang DH, Lee SK, Moon SH, Park DH, Lee SS, Seo 
DW, et al. Percutaneous transhepatic cholangioscopic intervention in the management of complete membranous occlusion of bilioenteric anastomosis: report of two cases. Gut Liver. 2009 Dec;3(4):352-55. doi: 10.5009/ gnl.2009.3.4.352.

7. Negi SS, Sakhuja P, Malhotra V, Chaudhary A. Factors predicting advanced hepatic fibrosis in patients with postcholecystectomy bile duct strictures. Arch Surg. 2004 Mar;139(3):299-303. doi: 10.1001/archsurg.139.3.299.

8. Quintero GA, Patico JF. Surgical management of benign strictures of the biliary tract. World J Surg. 2001 Oct;25(10):1245-50.

9. Chapman WC, Halevy A, Blumgart LH, Benjamin IS. Postcholecystectomy bile duct strictures. Management and outcome in 130 patients. Arch Surg. 1995 Jun;130(6):597-602; discussion 602-4.

10. Sicora SS. Management of post-cholecystectomy benign bile duct strictures: review. Indian J Surg. 2012 Feb; 74(1):22-28. doi: 10.1007/s12262-011-0375-6. 11. Капранов СА, Авалиани МВ, Кузнецова ВФ. Чреспеченочные эндобилиарные вмешательства при стриктурах желчных протоков. Анналы Хирург Гепатологии. 1997;2:123-31.

12. Багненко СФ, Савелло ВЕ, Кабанов МЮ, Корольков АЮ, Яковлева ДМ. Применение сменных транспеченочных каркасных стентов у больных с посттравматическими стриктурами печеночного и общего желчного протока. Вестн Хирургии им ИИ Грекова. 2008;167(2):69-71.

13. Oh $\mathrm{CH}$. Percutaneous transhepatic cholangioscopy in bilioenteric anastomosis stricture. Clin Endosc. 2016 Nov;49(6):530-32. doi: 10.5946/ce.2016.125.

14. Тулин АИ, Шавловскис Я. Чрескожноечреспеченочное дренирование Y-образной системой катетеров при рецидивирующих рубцовых стриктурах желчных протоков. Анналы Хирург Гепатологии. 2016;21(4):4754.

15. Mueller PR, van Sonnenberg E, Ferrucci JT Jr, Weyman PJ, Butch RJ, Malt RA, et al. Biliary stricture dilatation: multicenter review of clinical management in 73 patients. Radiology. 1986 Jul;160(1):17-22. doi: 10.1148/radiology.160.1.3715030.

16. Lee AY, Gregorius J, Kerlan RK, Gordon RL, Fiderman N. Percutaneous transhepatic balloon dilatation of biliary-enteric anastomotic strictures after surgical repair of jatrogenic bile duct injuries. PLoS One. 2012;7(10):e46478. doi: 10.1371/journal.pone.0046478.

\section{REFERENCES}

1. Gal'perin EI, Chevokin AIu. Faktory, opredeliaiushchie vybor operatsii pri «svezhikh» povrezhdeniiakh magistral'nykh zhelchnykh protokov [Factors determining the choice of surgery for "fresh" lesions of the main bile ducts]. Annaly Khirurg Gepatologii. 2009;14(1):4956.

2. Schmidt SC, Langrehr JM, Hintze RE, Neuhaus P. Long-term results and risk factors influencing outcome of major bile duct injuries following cholecystectomy. Br J Surg. 2005 Jan;92(1):76-82. doi: 10.1002/ bjs. 4775 .

3. Bonnel DH, Fingerhut AL. Percutaneous transhepatic balloon dilatation of benign bilioenteric strictures: long-term results in 110 patients. Am J Surg. 2012
Jun;203(6):675-83. doi: 10.1016/j.amjsurg.2012.02.001. 4. Gastaca M. Biliary complications after orthotopic liver transplantation: a review of incidence and risk factors. Transplant Proc. 2012 Jul-Aug;44(6):1545-49. doi: 10.1016/j.transproceed.2012.05.008.

5. Jung JY, Lee SK, Oh HC, Lee TY, Kwon SH, Lee $\mathrm{SS}$, et al. The role of percutaneous transhepatic cholangioscopy in patients with hilar strictures. Gut Liver. 2007 Jun;1(1):56-62. doi: 10.5009/gnl.2007.1.1.56.

6. Yang DH, Lee SK, Moon SH, Park DH, Lee SS, Seo DW, et al. Percutaneous transhepatic cholangioscopic intervention in the management of complete membranous occlusion of bilioenteric anastomosis: report of two cases. Gut Liver. 2009 Dec;3(4):352-55. doi: $10.5009 / \mathrm{gnl} .2009 .3 .4 .352$.

7. Negi SS, Sakhuja P, Malhotra V, Chaudhary A. Factors predicting advanced hepatic fibrosis in patients with postcholecystectomy bile duct strictures. Arch Surg. 2004 Mar;139(3):299-303. doi: 10.1001/archsurg.139.3.299.

8. Quintero GA, Patico JF. Surgical management of benign strictures of the biliary tract. World J Surg. 2001 Oct;25(10):1245-50.

9. Chapman WC, Halevy A, Blumgart LH, Benjamin IS. Postcholecystectomy bile duct strictures. Management and outcome in 130 patients. Arch Surg. 1995 Jun;130(6):597-602; discussion 602-4.

10. Sicora SS. Management of post-cholecystectomy benign bile duct strictures: review. Indian J Surg. 2012 Feb; 74(1):22-28. doi: 10.1007/s12262-011-0375-6.

11. Kapranov SA, Avaliani MV, Kuznetsova VF. Chrespechenochnye endobiliarnye vmeshatel'stva pri strikturakh zhelchnykh protokov [Transhepatic endobiliary interference with stricture of the bile duct]. Annaly Khirurg Gepatologii. 1997;2:123-31.

12. Bagnenko SF, Savello VE, Kabanov MI, Korol'kov AI, Iakovleva DM. Primenenie smennykh transpechenochnykh karkasnykh stentov u bol'nykh s posttravmaticheskimi strikturami pechenochnogo i obshchego zhelchnogo protoka [The use of replaceable transhepatic skeletal stents in patients with posttraumatic strictures of the hepatic and common bile duct.]. Vestn Khirurgii im II Grekova. 2008;167(2):69-71.

13. Oh $\mathrm{CH}$. Percutaneous transhepatic cholangioscopy in bilioenteric anastomosis stricture. Clin Endosc. 2016 Nov;49(6):530-32. doi: 10.5946/ce.2016.125.

14. Tulin AI, Shavlovskis Ia. Chreskozhnoe chrespechenochnoe drenirovanie Y-obraznoi sistemoi kateterov pri retsidiviruiushchikh rubtsovykh strikturakh zhelchnykh protokov [Percutaneous transhepatic drainage by the Y-shaped catheter system with recurrent scar cicles of the bile ducts]. Annaly Khirurg Gepatologii. 2016;21(4):47-54.

15. Mueller PR, van Sonnenberg E, Ferrucci JT Jr, Weyman PJ, Butch RJ, Malt RA, et al. Biliary stricture dilatation: multicenter review of clinical management in 73 patients. Radiology. 1986 Jul;160(1):17-22. doi: 10.1148/radiology.160.1.3715030.

16. Lee AY, Gregorius J, Kerlan RK, Gordon RL, Fiderman N. Percutaneous transhepatic balloon dilatation of biliary-enteric anastomotic strictures after surgical repair of jatrogenic bile duct injuries. PLoS One. 2012;7(10):e46478. doi: 10.1371/journal. pone. 0046478 . 
Адрес для корреспонденции

223041, Республика Беларусь,

Минская обл. и р-н, п. Лесной, 1 ,

У3 «Минская областная клиническая больница», тел. раб.: +375 17 265-22-13,

e-mail: varabeiproct@tut.by,

Воробей Александр Владимирович

\section{Сведения об авторах}

Воробей А.В., член-корреспондент НАН Беларуси, д.м.н., профессор, заведующий кафедрой хирургии ГУО «Белорусская медицинская академия последипломного образования».

Орловский Ю.Н., к.м.н., доцент кафедры хирургии ГУО «Белорусская медицинская академия последипломного образования».

Лагодич Н.А., врач-эндоскопист отделения эндоскопии УЗ «Минская областная клиническая больница». Орехов В.Ф., врач-рентгено-эндоваскулярный хирург ГУ «Республиканский научно-практический центр онкологии и мед. радиологии им. Н.Н. Александрова».

\section{Информация о статье}

Поступила 13 февраля 2017 г.

Принята в печать 27 апреля 2017 г.

Доступна на сайте 25 сентября 2017 2.
Address for correspondence

223041, Republic of Belarus,

Minsk region, Lesnoy, 1,

ME «Minsk Regional Clinical Hospital»,

Tel.: 37517 265-22-13,

e-mail: varabeiproct@tut.by,

Alexander V. Varabei

\section{Information about the authors}

Varabei A.V., Corresponding Member of the National Academy of Sciences of Belarus, MD, Professor, Head of the Surgery Department of SBE "Belarusian Medical Academy of Postgraduate Education".

Arlouski Y.N., PhD, Associate Professor of the Surgery Department of SBE "Belarusian Medical Academy of Postgraduate Education".

Lagodich N.A., Endoscopist of the Endoscopy Unit of ME "Minsk Regional Clinical Hospital”2.

Arehay V.F., X-ray-Endovascular Surgeon of SE " "Republican Scientific and Practical Center of Oncology and Medical Radiology named after N.N. Alexandrov".

\section{Article history}

Arrived 13 February 2017

Accepted for publication 27 April 2017

Available online 25 September 2017 